\title{
Character Education In The Novel Bumi Cinta and Novel Merindu Baginda Nabi by Habiburrahman El Shirazy
}

\author{
Herdawati $^{1}$ dan Nurizzati $^{2}$ \\ \{herdawati177@gmail.com ${ }^{1}$, nurizzati2138_@fbs.unp.ac.id ${ }^{2}$ \} \\ ${ }^{1,2}$ Universitas Negeri Padang, 082283813320, 081363028750, Indonesia
}

\begin{abstract}
This research is motivated by the weak character of the current generation of young people, both in terms of individuals and based on experience of the community, nation and state. Therefore, this study aims to describe the values of character education in the novel Bumi Cinta and the novel Merindu Baginda Nabi by Habiburrahman El Shirazy. Data was collected using a data inventory format, and analyzed based on the theory of sociological literature in accordance with the research objectives. The results showed that there are five values of character education that stand out in each novel namely novels Bumi Cinta and the novel Merindu Baginda Nabi by Habiburrahman El Shirazy. The five values include: (1) faith and piety, (2) honesty, (3) intelligence, (4) toughness, and (5) caring.
\end{abstract}

Keywords: Character Education, Novel Bumi Cinta, Novel Merindu Baginda Nabi

\section{Introduction}

The literary work is creative work that discusses the life of Air society is based on experience or the reality he saw in society. [23] argues k Arya literature is a means used by the authors to express feelings, ideas and all the problems of life and human life. The disclosure is realized based on the experience experienced by the author or seeing the reality that exists in the community. All life experiences and life becomes the object of creation of literary works. In the process of creating literary works, the authors digest the reality around them as outlined in a literary work. Literary works are written for the consumption of readers because readers also need [9].

[7] asserted that literary works can emerge from the author's experience or from the stories of others. Literary works fall into the category of fiction that must have an aesthetic purpose in it and can provide interesting stories and inner satisfaction for the reader. [19] states that literary works are the work of creative thoughts of the author as outlined in a story using language as the medium. Literary works emerge from the combination of social reality in the environment with the creativity of the author. Through the media of literary works, the author also wants to elevate existing life values to be able to understand the meaning and nature of life, because literary works are a reflection of a people's life.

Novel is one literary genres as a manifestation of contemplation and inner struggle of the writer, especially, about dialectic life of human being [14]. Literary works are written for the consumption of readers because readers also need [20]. The novel is a form of life and real behavior that is described in the form of an imitation that has interrelated elements [5], [22], [17].

According to [12] nvel is a work of prose that contains stories involving many characters in it and incorporates complex storylines as part of a very complicated life in a society. Responding to the fondness of the Indonesian state that is being haunted by 
worrying about the young generation in the future, Andrea Hirata with her various novels helps uncover the mystery of the story by displaying the values of character education that teachers are longing for now.

[9] states that the novel is a complex, unique organizational structure and expresses something (more of a nature) indirectly ". Novels as one of the literary products that have an important role in providing possibilities for human life, for example, can be taken several lessons to understand the nature of life. In the novel the author pours out the feelings he sees, is felt with the help of imagination. In addition, the author's imagination will not be possible if it does not have sufficient knowledge about other objective realities.

Literary works have a function and very closely related for people's lives [24]. [23], said that literature serves to provide pleasure and benefits. These two things complement each other; the pleasure derived from literature is not physical or material pleasure, but rather higher pleasure, namely contemplation that is not seeking profit. The benefits obtained from literary works are literary works able to create a more interesting atmosphere, more vibrant, and provide enjoyment for its readers so that what is needed by the community can be fulfilled properly. Literary works written certainly contain advice for the reader [4].

[9] states that as a miniature world, literary works function to infest a large number of events that have been framed in patterns of creativity and imagination. As an imaginary work, fiction offers a variety of human and humanitarian problems, life, and life. Of course in literature there are many noble values that can be emulated by students. According to [2] the novel is not only a fiction, but can also be a reference or reading to understand the culture of an ethnic group. Novels that are in great demand by readers at the moment, namely strories that have a lot of themes related to the reader [1].

Each type of novel can be studied using many approaches, one of them is the novel Bumi Cinta and the novel Merindu Baginda Nabi by Habiburrahman El Shirazy. Novel Bumi Cinta and novel Merindu Baginda Nabi by Habiburrahman El Shirazy studied by the researchers hooked up an value - the value of character education. This study is a means of knowledge that the novel Cinta Cinta and the novel Merindu Baginda Nabi by Habiburrahman El Shirazy have a positive value when read by all groups, especially teenagers .

[12] explains that character education is the overall interpersonal relational dynamics with various dimensions both from within and from outside. It is expected that each person can experience his freedom more so that he can be more responsible for his own growth as a person and the development of others in their lives. In short, character education can be interpreted as a social assistance so that individuals can grow in living their freedom in living together with others in the world. Character education as a pedagogy provides three important meanings in every educative and intentional intervention for the advancement of education. This mantra is individual, social, and moral.

Character education has recently has regained its importance in the word of education [10]. [18] explains character education targeting the character of child development which is a combination of psychological characteristics that activate and motivate children to function as effective moral agents that have social attitudes and are responsible and ethical and ethical. According to [3] more character refers to the results of the process of inculcation of values. The issue of what values are internalized depends on the value system that is upheld or agreed upon in society. Character education is a values related to one's morals that needs to be applied in everyday life [6].

[11] put forward five focus values of character education that are sourced from the development of human dignity and dignity components (HMM) and Pancasila values. The 
values of character education include: (1) faith and piety to God Almighty, (2) honesty, (3) intelligence, (4) toughness, and (5) caring.

This type of research is a qualitative research with descriptive analysis method. According to [19] qualitative research is research carried out by not using numbers, but rather using researchers' appreciation of the interactions between concepts being studied empirically. According to [13], the descriptive method of analysis is done by describing the facts which are then followed by analysis. Etymologically description and analysis mean outlining. It does not merely describe but also provides sufficient understanding and explanation. The data in this study are stories that illustrate the values of character education contained in the novel Bumi Cinta and the novel Merindu Baginda Nabi by Habiburrahman El Shirazy. Data sources in this study are the novel Bumi Cinta and the novel Merindu Baginda Nabi by Habiburrahman El Shirazy.

The novel Bumi Cinta is the brainchild of Habiburrahman El Shirazy's thoughts, published by the publisher Republika. This novel is the first printing in February 2019. The novel consists of forty titles and a total of 546 pages. The cover design of this novel, which is in blue dongker. Furthermore, it is equipped with pictures of cars lined up neatly parked on a snowcovered roadside. In addition, with the same author the novel Merindu Baginda Nabi, also published by the publisher Republika. This novel is the second printing in November 2018 . The novel consists of fourteen story titles and totaling 176 pages. The cover design of this novel is green combined with white. Furthermore, it is equipped with a mosque dome image and white clouds and flying birds.

The data collection techniques of this research are as follows: 1) reading and understanding as a whole this novel Bumi Cinta and the novel Merindu Baginda Nabi by Habiburrahman El Shirazy, 2) marking every part of the novel that contains the values of character education , 3) inventorying data in the format data collection. The data validation technique in this study is to use triangulation techniques. According to [8] triangulation is a data validation checking technique that uses something else outside the data for the purposes of checking or comparing data. The use of other observers helps reduce skewness in data collection. Data analysis techniques were carried out namely: (1) identifying data, (2) analyzing data, and (3) summarizing the findings.

The novel Bumi Cinta and the novel Merindu Baginda Nabi by Habiburrahman El Shirazy are novels with the theme of the struggle of life. In the novel Bumi Cinta and the novel Merindu Baginda Nabi by Habiburrahman El Shirazy, the writer tries to write about the struggle of one's life from various tests and continues to strive to achieve his education and ideals. Obtained education certainly cannot be separated from parental upbringing. The novel Merindu Baginda Nabi provides very valuable lessons for the educational process . This can be seen in the struggle of the characters in this novel who are always excited and never give up despite the many obstacles faced. The reason for the researchers choosing the values of character education in this novel is that many teenagers are now easily discouraged from leaving education.

Habiburrahman El Shirazy is an Indonesian writer and scholar who has an international reputation. He is the first Southeast Asian writer to get an award from The Istanbul Foundation for Sciences and Culture, Turkey. In addition, the cultural dropout from Al Azhar University Cairo, has been rewarded with various awards from within and outside the country. Among these; Southeast Asian Archipelago Literature Award, Paramadina Award 2009, Award for Archipelago Islamic Arts and Arts Award from the Chief Minister of the State of Sabah, Malaysia, Figure of Change from the Republika Daily. In 2008, Insani Undip Semarang, ordained the author of these Love Verses as Novelist No. 1 Indonesia. 
This research was conducted on the grounds that the novel Bumi Cinta and the novel Merindu Baginda Nabi by Habiburrahman El Shirazy were interesting to analyze, and had never been studied before. In addition, because in the novel Bumi Cinta and the novel Merindu Baginda Nabi by Habiburrahman El Shirazy, many values of character education are found. The values of character education include: (1) faith and piety, (2) honesty, (3) intelligence , (3) toughness, and (5) caring .

Based on the description above, the purpose of this study is as follows. First, describing the values of character education of faith and piety to God Almighty in the novel Bumi C Inta and the novel Merindu Baginda Nabi by Habiburrahman El Shirazy. Second, describe the values of honesty character education in the novel Bumi Cinta and the novel Merindu Baginda Nabi by Habiburrahman El Shirazy. Third, describe the values of intelligence character education in the novel Bumi C Inta Nabi and the novel Merindu Baginda Nabi by Habiburrahman El Shirazy. Fourth, describe the values of tough character education in the novel Bumi Cinta Nabi and the novel Merindu Baginda Nabi by Habiburrahman El Shirazy . Fifth, describe the values of caring character education in the novel Bumi Cinta Nabi and the novel Merindu Baginda Nabi by Habiburrahman El Shirazy.

\section{Text Formatting}

\subsection{Cication and references}

Based on the research findings, there are values of character education in the novel Bumi Cinta and the novel Merindu Baginda Nabi by Habiburrahman El Shirazy. The educational values are limited in five ways including (a) faith and piety, (b) honesty, (c) toughness, (d) toughness, and (e ) intelligence. The character education values that stand out in the novel Bumi Cinta and the novel Merindu Baginda Nabi by Habiburrahman El Shrazy will be described as follows.

Table 1. Data on Character Education Values

\begin{tabular}{|c|c|c|c|c|c|c|c|c|}
\hline \multirow[t]{2}{*}{ No } & \multirow{2}{*}{$\begin{array}{c}\text { Data } \\
\text { Source } \\
\text { Code }\end{array}$} & \multirow{2}{*}{$\begin{array}{l}\text { Data } \\
\text { Code }\end{array}$} & \multirow[b]{2}{*}{ Marker } & \multicolumn{5}{|c|}{ Values of Character Education } \\
\hline & & & & 1 & 2 & 3 & 4 & 5 \\
\hline 1 & 01 & 1 & Faith & $\checkmark$ & & & & \\
\hline 2 & 02 & 2 & Piety & $\sqrt{ }$ & & & & \\
\hline 3 & 01 & 3 & Keep promise & & $\checkmark$ & & & \\
\hline 4 & 02 & 4 & To be responsible & & $\checkmark$ & & & \\
\hline 5 & 01 & 5 & Intelligent & & & $\checkmark$ & & \\
\hline 6 & 02 & 6 & Intelligent & & & $\sqrt{ }$ & & \\
\hline 7 & 01 & 7 & Not hopeless & & & & $\checkmark$ & \\
\hline 8 & 02 & 8 & Not hopeless & & & & $\checkmark$ & \\
\hline 9 & 01 & 9 & Helpful & & & & & $\checkmark$ \\
\hline 10 & 02 & 10 & $\begin{array}{ll}\text { Comply } & \text { with } \\
\text { Regulations } & \end{array}$ & & & & & $\sqrt{ }$ \\
\hline
\end{tabular}

Information

$1=$ Faith and piety

2 = Honesty

$3=$ Intelligence 
$4=$ toughness

$5=$ Caring

\section{a. Values Character Education Faith and Devotion to God Almighty}

Faith is a belief or belief in God Almighty, while piety means to carry out all commands and avoid all His prohibitions. The values of the character education of faith and piety to God Almighty contained in the novel Bumi Cinta by Habiburrahman El Shirazy are as follows.

(1) "Ia harus semakin merapat kepada Allah. Tak ada yang benar-benar mampu menyelamatkan imamnya kecuali Allah. Moskwa bukan Madinah. Jika di Madinah aroma kesucian orang-orang saleh begitu terasa, di Moskwa yang ia rasakan adalah aroma perempuan cantik Rusia seperti Yelena dan Anastasia Palazzo yang mengusik ketenangan jiwa" (BM, 2019, p. 94)

Data 1 above illustrates that there is value in character education in the novel Bumi Cinta about faith. As a religious person, of course always draw closer to God. In this case , the figure of Ayyas who always remembers God whenever and wherever he is. Because wherever we are tests and trials will always come. Therefore, by always remembering God we will avoid things that can shake the priest and avoid disobedience.

The values of character education of faith and piety to God Almighty contained in the novel Merindu Baginda Nabi by Habiburrahman El Shirazy are as follows.

(2) "Azan Ashar berkumandang. Rifa terpaksa menyudahi diskusi mereka, sebab ia harus bersiap shalat berjamaah dan mengikuti pengajian rutin selepas sholat Ashar. Pengajian yang sangat ia sukai dan selalu ia rindukan, yaitu mengaji kitab tipis AlMinahus Saniyyah karya Imam Asy-Sya'rani yang langsung diampu oleh abahnya." (MBN, 2018 p. 34)

Data 2 above, is the value of character education contained in the novel Merindu Baginda Nabi by Habiburrahman El Shirazy who carries out orders and away from God's prohibition. Quote the data above, illustrates that figure Rifa obediently to practice prayer without delay. The atmosphere depicted when Rifa was even though he was having a small discussion with his friend and immediately stopped him. After praying, Rifa took part in the routine activities at the pesantren and examined the thin book which was directly influenced by his Abah. It can be seen that the educational value found in the Rifa figure is to always prioritize the teachings of his religion.

\section{b. The values of honesty character education}

Honesty is a small part of the value of life that must be owned by humans because of high value. The values of honesty character education contained in the novel Bumi Cinta by Habiburrahman El Shirazy are as follows.

(3) "Ia berjanji kepada Allah, jika Sofia selamat, ia akan menikahinya dan menjadikannya sebagai teman berjuang di jalan-Nya sampai maut datang menjemput" (BC, 2019, p. 542)

Data 3 above, illustrates the value of character education contained in the novel Bumi Cinta by Habiburrahman El Shirazy, which holds promise. Ayyas figure who promised God, if Sofia's character can be saved then he will marry her. In the above statement, Sofia who was unconscious after she was shot by a stranger. Ayyas figure tries to save his life by rushing to take Sofia to the hospital to get help.

The values of honesty character education contained in the novel Merindu Baginda Nabi by Habiburrahman El Shirazy are as follows. 
(4) "Usai lulus SMA dengan paket C, Mas Sokib pamit ingin merantau ke Jakarta. Abah tidak melepas anak asuhnya tanpa jalan dan rencana yang jelas. Ia menghubungi beberapa kenalannya di Jakarta. Seorang teman sekolah abah di kampung dulu, namanya Pak Mustain sudah jadi orang Jakarta dan bekerja di sebuah biro umrah di daerah Jakarta Timur, Mas Sokib dititipkan pada temannya itu" (MBN, 2018, p. 14)

Data 4 above, is one of the values of character education contained in the novel Merindu Baginda Nabi by Habiburrahman El Shirazy, which holds promise. Abah figure (who is a boarding school nurse) who is responsible for foster children. He could not release his foster children to go abroad with unclear plans. He contacted his friends in Jakarta to leave his foster children and find him a job. For obvious reasons, the Abah character will calmly release his foster children to leave.

\section{c. The values of intelligence character education}

Intelligence is the perfect development of a person's mind to think, understand, sharp mind, and perfect growth of his body. The values of intelligence character education contained in the novel Bumi Cinta by Habiburrahman El Shirazy are as follows.

(5) "Devid dulu di SMP termasuk siswa cerdas, selalu masuk tiga besar. bahkan dirinya saja, ia rasakan saat SMP dulu masih kalah dengan Devid" (BM, 2019, p. 20)

Data 5 above, is the value of character education contained in the novel Bumi Cinta by Habiburrahman El Shirazy namely intelligence. Devid figure who is one of the close friends of Ayyas figures since middle school. Devid's figure is one of the smart students in his class. He always ranked in the top 3 while in middle school. In the quote above, it is illustrated that Devid's character is smarter than Ayyas .

The values of intelligence character education contained in the novel Merindu Baginda Nabi by Habiburrahman El Shirazy are as follows.

(6) "Bahasa Inggris Rifa memukau semua yang hadir di seminar internasional itu. Menteri Sosial secara khusus menjanjikan kepada Rifa beasiswa untuk kuliah selepas SMA. "Silahkan pilih kampus di mana saja di dunia ini akan saya siapkan beasiswanya," disaksikan Pak Nur dan beberapa orang didekatnya saat makan siang bersama" (MBN, 2018 hlm.104)

Data 6 above, there is the value of intelligence education. This illustrates that Rifa is able to master English well. The use of good English, can lead him to get a scholarship to study after graduating from high school.

\section{d. The values of Resilience character education}

Resilience is the strength that causes a person to survive, strong, able to overcome the burden, and not easily discouraged in the face of trials. The values of resilience character education contained in the novel Bumi Cinta by Habiburrahman El Shirazy are as follows.

(7) "Tapi ia seperti tidak bisa lagi bergerak. Ia kumpulkan segenap tenaga untuk bergerak. Tangan kirinya ia paksa untuk bergerak. Tidak bisa. Tangan kanan. Tidak bisa. Seolah tangan itu bukan tangannya lagi. Seolah tanahnya telah hilang. Ia mencoba sekali lagi. Ia kumpulkan segenap semangatnya. Ia harus bisa mengambil ponselnya tangan kirinya sedikit bisa digerakkan. Ia sedikit merasa ada harapan. Ia terus memaksa. Tangan itu bergerak ke arah saku 
paltonya. Terus ia paksa. Akhirnya bisa meraih ponselnya” (BC, 2019, p. 164)

In the quote above, there is the value of toughness character education that is not hopeless. Yelena figure who continues to try to reach his cellphone to tell his friends that he was having a small accident. The accident broke his hand, his legs could not be moved. He kept trying so he could save himself from the cold snow that would cover his entire body.

The values of resilience character education contained in the novel Merindu Baginda Nabi by Habiburrahman El Shirazy are as follows.

(8) "Aku akan datangi rumahnya dan minta penjelasan. Kalau aku memang ada salah sama dia, aku akan minta maaf." (MBN, 2018, p. 75)

Data 8 above, is one of the values of character education contained in the novel Merindu Baginda Nabi by Habiburrahman El Shirazy, which is certainly not hopeless. This is illustrated by the figure of Rifa who always tried to invite Arum to talk with him but Arum did not want to. Rifa is confused about what exactly happened with his classmate. Since Rifa returned from America, Arum's attitude immediately changed to him. Therefore, Rifa wants to come to Arum's house to ask for an explanation about the change in his attitude to Rifa. Rifa always tries to get Arum to talk to him, if he has something wrong with Arum, he will apologize.

\section{e. The values of character education into care early}

Kep eduli early is one way to maintain relationships with others, whereas others feel the commitment and personal responsibility. The values of caring character education contained in the novel Bumi Cinta by Habiburrahman El Shirazy are as follows.

(9) "Baiklah. Mari kita selamatkan nyawa umat manusia malam ini semampu kita"

(BM, 2019, p. 171)

Data 9 above, is one of the values of character education contained in the novel Bumi Cinta by Habiburrahman El Shirazy, which is sure to be helpful. The quote above illustrates that the Ayyas figure is eager to save someone who is experiencing hardship. Ayyas thinks that our fellow humans should help one another. Right now other people who need our help, and who knows tomorrow or the day after tomorrow we need someone else's help. Ayyas' figure who tries to save the life of a woman who turns out to be a woman named Yelena is a friend of her.

The values of caring character education contained in the novel Merindu Baginda Nabi by Habiburrahman El Shirazy are as follows.

(10) "Kalau saya sih, tidak masalah mau diletakkan di kelas berapa nanti oleh pihak sekolah. Saya ikuti kebijakan sekolah dengan ikhlas. Besok saya akan datang ke sekolah, insya Allah.” (MBN, 2018, p. 32)

Data 10 above, is one of the values of character education contained in the novel Merindu Baginda Nabi by Habiburrahman El Shirazy, which is sure to comply with regulations. Rifa figure who has a big heart accepts the school's decision about staying in class or continuing to grade. He highly valued the school's decision that he went to America to exchange lessons and was also a messenger from the school. Therefore, he waited for the school's policy on this and accepted it sincerely. 


\subsection{Acknowledgements}

The author thanks Dr. Nurizzati, M.Hum., Who has guided the author in completing this research article. Thank you authors say to parents who have provided support, prayers and have provided facilities.

\section{References}

[1] Akbar Syahrizal, Retno Winarti, Andayani.: Kajian Sosiologi Sastra dan Nilai Pendidikan dalam Novel Tuan Guru Karya Salman Faris. Jurnal Pendidikan Bahasa dan Sastra Vol. 1 No. 1 p. 54-68 (2013)

[2] Dewi, Ni Luh Lina Agustini, dkk.: Analisis Nilai-Nilai Pendidikan Karakter Novel Sepatu Dahlan Karya Khrisna Pabichara Dan Relevansinya Terhadap Pengajaran Pendidikan Karakter Sekolah Di Indonesia. E-Jurnal Pendidikan Bahasa dan Sastra Indonesia, Undiksha 2 (1): 1-10 (2014)

[3] Fitrina, Yulia, dkk.: Pendidikan Karakter dalam Novel Negeri 5 Menara Karya Ahmad Fuadi dan Novel Laskar Pelangi Karya Andrea Hirata: Tinjauan Sosiologi Sastra. Jurnal Bahasa, Sastra dan Pembelajaran 1 (1): 64-79 (2013)

[4] Irma, Cintya Nurika.: Nilai-nilai Pendidikan Karakter dalam Novel Ibuk Karya Irwan Setyawan. Jurnal Retorika 11 (1): 14-22 (2018)

[5] Mashita, Mutia, Erizal Gani, Bakhtaruddin Nst.: Nilai-nilai Pendidikan dalam Novel Sepatu Dhlan Karya Khrisna Pabichara dan Implikasi dalam Pembelajaran Bahasa Indonesia. Jurnal Pendidikan Bahasa dan Sastra Indonesia 1 (2): 77-163 (2013)

[6] Meisusri, silvi, Yasnur Asri, M. Ismail Nst.: Sisi Humanisme Tere Liye dalam Novel Rembulan Tenggelam Di Wajahmu. Jurnal Pendidikan Bahasa dan Sastra Indonesia 1 (1): 222-229 (2012)

[7] Musliah Siti.: Sisi Humanisme Tere Liye dalam Novel Rembulan Tenggelam Di Wajahmu. Jurnal Parole 1 (5): 681-690 (2018)

[8] Moleong, Lexy J.: Metode Penelitian Kualitatif. Bandung: Remaja Rosdakarya (2009)

[9] Nurgiyantoro, Burhan dan Anwar Efendi.: Prioritas Penentuan Nilai Pendidikan Karakter dalam Pembelajaran Sastra Remaja. Cakrawala Pendidikan XXXII (3): 382-393 (2013)

[10] Novianti, N.: Bildungsroman for character education in higher education: An Indonesian context. International Journal of Education, 9 (2), 126-132: dx.doi.org/10.17509/ije.v9i2.5474 (2017)

[11] Prayitno dan Afriva Khaidir.: Model Pendidikan Karakter Cerdas. Padang: UNP Press (2011)

[12] Pusvita, Winda Dewi.: Nilai-Nilai Pendidikan Karakter Pada Novel Ayah Karya Andrea Hirata. Jurnal Leksema 2 (1): 51-63 (2017)

[13] Ratna, Nyoman Kutha.: Teori, Metode, dan Teknik Penelitian Sastra. Yogyakarta: Pustaka Pelajar (1012)

[14] Riadi, Sugeng dan Emzir.: Sufistic and transformative pedagogic values in syaikh siti jenar novel by Agus Sunyoto Genetic Structuralism. International Journal of Language Education and Culture Review(IJLECR) 1 (1): 79-86 (2015)

[15] Shirazy, Habiburrahman El.: Merindu Baginda Nabi. Jakarta: Republika (2018)

[16] Shirazy, Habiburrahman El.: Bumi Cinta. Jakarta: Republika (2019)

[17] Saraswati, Intan, Suyitni, Herman J. Waluyo.: Novel Lalita Karya Ayu Utami (Kajian Psikologi Sastra dan Nilai Pendidikan). Jurnal Penelitian Bahasa, Sastra Indonesia, dan Pengajaran 1 (3): 490-503 (2014) 
[18] Sulastri, Saptiani dan Al Ashadi Alimin.: Nilai Pendidikan Karakter Kerja Keras dalam Novel 2 Karya Donny Dhirgantoro. Jurnal Pendidikan Bahasa 6 (2): 156-168 (2017)

[19] Syafrona, Andrika.: Masalah Sosial dalam Novel Rembulan Tenggelam Di Wajahmu Karya Tere Liye: Kajian Sosiologi Sastra. Jurnal Pendidikan Bahasa dan Sastra Indonesia 1 (2): 241-248 (2013)

[20] Susanti, Marlina, Hamidin, dan M. Ismail Nst.: Nilai Pendidikan Karakter dalam Novel Nazar-nazar Jiwa Karya Budi Sulistyo En-Nafi. Jurnal Pendidikan Bahasa dan Sastra Indonesia 1 (2): 241-317 (2013)

[21] Tantri, Ade Asih Susiari.: Nilai-Nilai Pendidikan Karakter dalam Novel Tantri (Perempuan Yang Bercerita) Karya Cok Sawitri sebagai Alternatif Pembelajaran Sastra di Sekolah Dasar. Education and Language International Conference Proceedings Center for International Language Development of Unissula, halaman 57-68 (2017)

[22] Wulandari, Suci, Yant Mujiyanto, Sri Hastuti.: Novel Ayat-ayat Cinta Karya Habiburrahman El Shirazy dan Novel Kasidahkasidah Cinta Karya Muhammad Muhyidin. Jurnal Penelitian Bahasa, Sastra Indonesia, dan pengajaran 1 (3): 562-572 (2014)

[23] Yenhariza, Devi.: Nilai-Nilai Pendidikan Dalam Novel Eliana karya Tere Liye. Jurnal Pendidikan Bahasa dan Sastra Indonesia 1 (1): 167-174 (2012)

[24] Yuniarti, Netti.: Analisis Aspek Kejiwaan Tokoh dan Nilai Pendidikan Karakter Novel Surat Dahlan Karya Khrtisna Pabichara (Kajian Psikologi Sastra). Jurnal Pendidikan Bahasa 2 (2): 219-235 (2013) 